\title{
EFFECT OF SOLAR RADIATION ON SURVIVAL OF INDICATOR BACTERIA IN BATHING WATERS
}

\author{
Sigrid Deller, Franz Mascher, Sabine Platzer, Franz Ferdinand Reinthaler, Egon Marth \\ Institute of Hygiene, Medical University of Graz, Austria
}

\section{SUMMARY}

Sunlight exposure is considered to be the most important cause of "natural disinfection" in surface water environments. The UV-B portion of the solar spectrum is the most bactericidal, causing direct (photo-biological) DNA damage.

In the present experimental study, the effect of solar radiation on the elimination of bacteria in water, especially in surface water, was studied. The influence of depth and UV-B transmittance of water was determined. Comparing Escherichia coli, Enterococcus faecalis, Pseudomonas aeruginosa and Staphylococcus aureus, Enterococcus faecalis proved to be the most resistant organism. Pseudomonas aeruginosa was shown to be the most sensitive indicator bacterium among the tested microorganisms.

Results show a significant correlation between radiation intensity and reduction rates. Best elimination of microorganisms occurs on the water surface; with increasing water depth, there is less UV radiation to inactivate bacteria. High turbidity substantially reduces UV-B transmittance in water causing decreased elimination efficiency.

The results of the present study show that sunlight, given an appropriate intensity and good water transparency is suitable to inactivate fecal indicator bacteria within a few hours in surface waters and therefore also in bathing waters.

Key words: bacterial inactivation, sunlight, UV radiation, surface water, small-scale bathing ponds, fecal indicator bacteria

Address for correspondence: Franz Mascher, Institute of Hygiene, Medical University, Universitaetsplatz 4, $8010 \mathrm{Graz}$, Austria. E-mail: franz.mascher@meduni-graz.at

\section{INTRODUCTION}

The germicidal action of sunlight has long been recognized (1), but the ecological implications and the potentials for practical applications have to be researched more thoroughly. UV light has been shown to effectively inactivate indicator bacteria and pathogens $(2,3)$. The effectiveness of UV light in biological inactivation arises primarily from the fact that DNA molecules absorb UV photons between 200 and $300 \mathrm{~nm}$, with peak absorption at $260 \mathrm{~nm}$. UV-A (wavelengths, 320 to $400 \mathrm{~nm}$ ) causes only indirect damage to DNA, proteins and lipids through reactive oxygen intermediates. UV-B (wavelengths, 290 to $320 \mathrm{~nm}$ ) causes both direct and indirect damage because of the strong absorption by DNA at wavelength below $320 \mathrm{~nm}$ (4). UV-C is absorbed in the early stratosphere and does not reach the earth's surface. Studies by Sinton et al. and Davies-Colley et al. $(5,6)$ determined UV-B radiation to be the most significant factor in the inactivation of somatic coliphages.

The objective of this study was to evaluate the effectiveness of solar radiation to reduce the microbial contamination of water bodies, particularly with regard to bathing waters. In Austria and other central European countries artificial bathing ponds are built more frequently. Small-scale bathing ponds are artificial ponds, less than $15,000 \mathrm{~m}^{2}$, sealed from the groundwater and intended for bathing, which can be drained (with or without mechanical equipment) (7). The water is kept clean solely through the ecosystem of micro- and macro-organisms; there is no additional disinfection of water. The small water surface and volume presents certain hazards for the hygienic balance of such small-scale bodies of water. Especially freshwater bathing sites may be small and enclosed bodies of water and fairly static with an increased health risk for the bathers (8).

Following artificial contamination of a small-scale bathing pond with fecal indicator bacteria, a 4-log reduction was observed within 4 to 8 hours (9). The literature reports significantly longer reduction times (T90) for indicator bacteria in surface water (10). The effectiveness of solar radiation to reduce microbial contamination of water was examined by an experimental study considering different UV transmittances and depths of water. Furthermore, we compared the survival of a range of bacteria associated with feces, when exposed to sunlight.

\section{MATERIALS AND METHODS}

Materials: Escherichia coli strain ATCC 25922, Enterococcus faecalis (ATCC 29212), Pseudomonas aeruginosa (ATCC 27653), and Staphylococcus aureus (ATCC 6538) were cultured on Tryptone-Soy-Agar (Oxoid CM 131) at $37{ }^{\circ} \mathrm{C}$ overnight, inoculated the next day into a Tryptone-Soy-Broth (Oxoid CM 129) and incubated another 24 hours at $37^{\circ} \mathrm{C}$. Thereafter, bacteria were washed three times with saline solution and harvested by centrifugation.

Experiments were performed in uncovered glass vessels (diameter $90 \mathrm{~mm}$, height $50 \mathrm{~mm}$ ) containing $300 \mathrm{ml}$ of sterile water, contaminated with bacteria at a final concentration of approximately $10^{4}$ to $10^{5} \mathrm{cfu} / \mathrm{ml}$. Prior to irradiation, a portion 
of the bacterial suspension was removed and serially diluted to determine the initial cell concentration. Magnetic stir-bars were used to ensure adequate mixing of water during the whole experiment. To simulate field conditions water was used with a temperature of $23{ }^{\circ} \mathrm{C}$ to $25{ }^{\circ} \mathrm{C}$. Exposed to sunlight the water temperature increased to a maximum value of $32{ }^{\circ} \mathrm{C}$.

Solar Radiation: The intensity of UV radiation was recorded every 30 minutes throughout the whole experiment by the UVBiometer Model 501A (Solar Light Co.), at the meteorological station Graz-north.

UV Transmittance (UVT): The UV transmittance was analyzed photometrical at a wavelength of $254 \mathrm{~nm}$.

Study Design: All experiments were carried out at the Institute of Hygiene, Medical University of Graz, during the summers of 2001, 2002 and 2003. The survival of the bacteria was measured as a function of the exposure to radiation. The location for sunlight exposure was the flat roof of the "Resowi-centre", the School of Law and Social Sciences, Karl-Franzens-University of Graz, Universitätsstraße 15, 8010 Graz.

In the first step, the correlation between UV intensity and reduction rate of Escherichia coli was determined during the course of the day. A contaminated water sample was exposed to the sunlight for 30 minutes. Thereafter the inactivation rate was determined and the sample was discarded. This procedure was repeated every hour over a whole day (from 9:00 to 19:00).

In the second step, the influence of different UV transmittances of water on solar inactivation of Escherichia coli was tested. Samples were taken every 10 minutes during the first hour and every 20 minutes thereafter. The degree of UV transmittance (UVT/cm; wavelength $254 \mathrm{~nm}$ ) was defined by adding different amounts of instant coffee as recommended by the Austrian Standards Institute (11). We tested the effect of instant coffee on the survival of Escherichia coli and no influence on bacterial growth rate could be observed.

In the third step, the influence of water depth on solar inactivation of Escherichia coli was tested. We used polyethylene terephtalate bottles because of their ability to transmit all wavelengths in sunlight (12-16). In order to determine the suitability

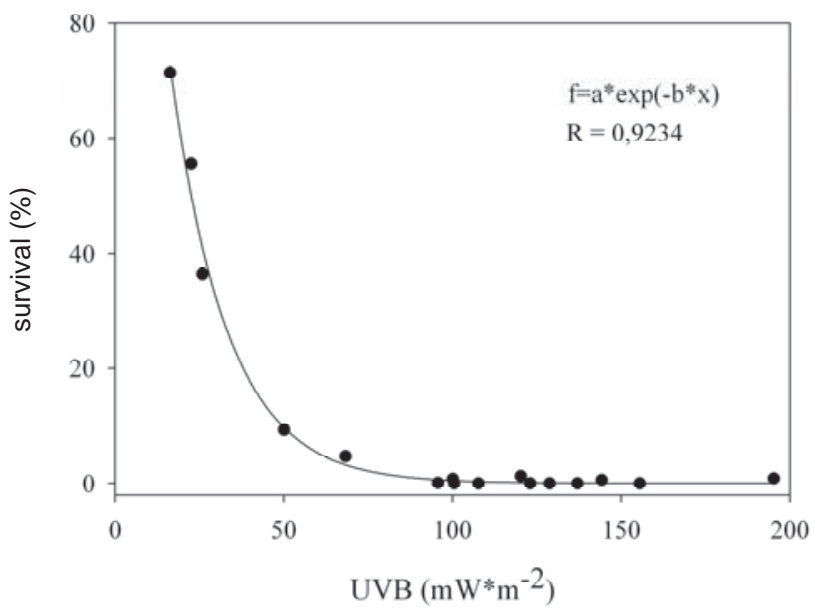

Fig. 1. Reduction of Escherichia coli related to varied UV-B values. Initial concentration of Escherichia coli: $2.8 \times 10^{4} \mathrm{cfu} / \mathrm{ml}$; UVB: $20-200 \mathrm{~mW} / \mathrm{m}^{2}$. for PET-bottles to examine the influence of water depth on the reduction of indicator bacteria, different sizes of PET-bottles were tested. These bottles were exposed directly to sunlight; bottles filled with 21 and bottles filled with 0.51 were compared. Samples were taken every 10 minutes. A third bottle was not exposed to sunlight and used as a reference. In a further step the PET-bottles (volume $500 \mathrm{ml}$ ) were fastened at different depths $(0 \mathrm{~cm}, 10 \mathrm{~cm}$, $20 \mathrm{~cm}$ and $30 \mathrm{~cm}$ ) to an iron stand and placed into a water container. The bottles were filled with contaminated water (Escherichia coli, $10^{4} \mathrm{cfu} / \mathrm{ml}$ ) and exposed to sunlight within the water container. Samples were taken every 20 minutes.

In a fourth step, the UV sensitivity of Escherichia coli, Pseudomonas aeruginosa, Enterococcus faecalis and Staphylococcus aureus was determined. Samples were taken every 10 minutes within an exposure time of 100 minutes.

Statistics: The statistical significance of parameters was determined using a generalized linear regression model (Fig. 1) and the Wilcoxon-test (Fig. 2-5).

\section{RESULTS}

Solar UV intensity shows both seasonal (because of changes in the earth's angle of tilt) and daily variation. Figure 1 represents the variation in received solar UV radiation intensity and therefore variation in reduction rates of Escherichia coli. Reduction rates of Escherichia coli show a significant correlation with radiation intensity $\left(\mathrm{R}^{2}=0.92\right)$.

In addition, differences between varying indicator bacteria were found. Enterococcus faecalis proved to be significantly more resistant to sunlight than Pseudomonas aeruginosa, Escherichia coli and Staphylococcus aureus. While initial concentration of Pseudomonas aeruginosa was reduced by more than 3 logs after only 40 minutes, there was no significant reduction after the same period in the case of Enterococcus faecalis. Only after 100 minutes a reduction of 2 logs was found for Enterococcus faecalis. Escherichia coli was eliminated much more rapidly than Enterococcus faecalis $(\mathrm{p}<0.02)$, but was more resistant than Pseudomonas

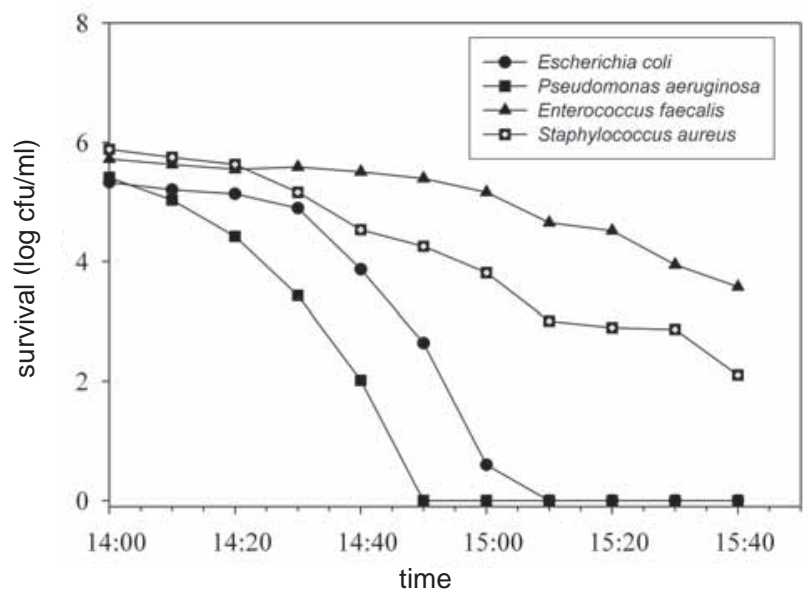

Fig. 2. Reduction of Escherichia coli, Pseudomonas aeruginosa, Enterococcus faecalis and Staphylococcus aureus in water; UVB maximum: $213 \mathrm{~mW} / \mathrm{m}^{2}$. 
aeruginosa $(\mathrm{p}<0.02)$. Staphylococcus aureus showed sensitivity similar to Escherichia coli (Fig. 2).

UV transmittance contains the influence of turbidity and absorption of the light transmitting the water. Turbidity is used as a parameter to characterize the optical properties of liquids containing absorbers and scatterers, i.e. suspended particles. When the influence of different UV transmittances was tested, a correlation between UV transmittance and reduction rate of Escherichia coli was observed. High UV transmittance ( $86 \%$ and $24 \%$ ) led to an inactivation of Escherichia coli within one hour (initial concentration: $2 \times 10^{4} \mathrm{cfu} / \mathrm{ml}$ ), UV transmittance of $10 \%$ resulted in an inactivation within two hours, whereas low UV transmittance (2\%) showed a reduction rate of only $50 \%$ in two hours (Fig. 3 ). The difference in reduction rates of Escherichia coli in water with varied UV transmittance is at least significant $(\mathrm{p}<0.05)$ with the exception of one case (comparison between $86 \%$ and $24 \%$ UVT). The difference between $86 \%$ and $2 \%$ and the difference between $24 \%$ and $2 \%$ are very significant $(\mathrm{p}<0.01)$.

Furthermore, we found a correlation between water depth and reduction rate of Escherichia coli. Total die-off of Escherichia

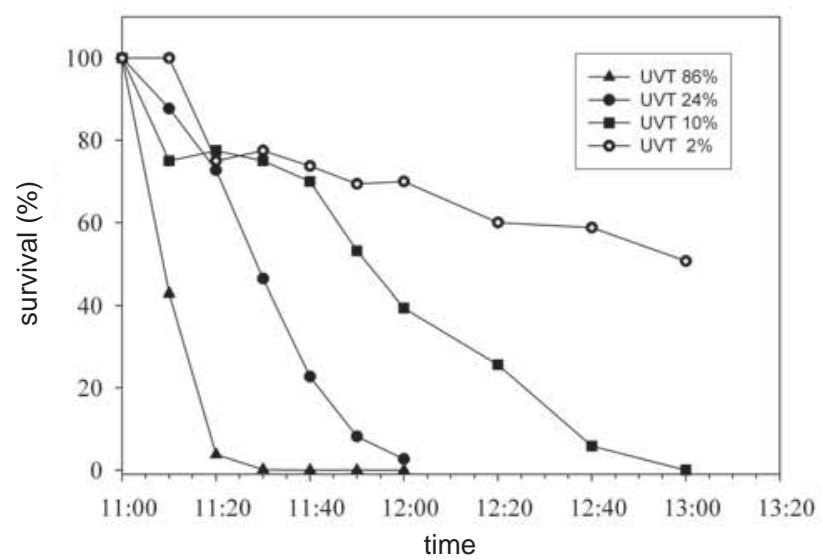

Fig. 3. Reduction of Escherichia coli in water with different UV transmittance (UVT/cm and $254 \mathrm{~nm}$ wavelength in percent). Initial concentration of Escherichia coli: $2.0 \times 10^{4} \mathrm{cfu} / \mathrm{ml}$; UVB maximum: $222 \mathrm{~mW} / \mathrm{m}^{2}$.

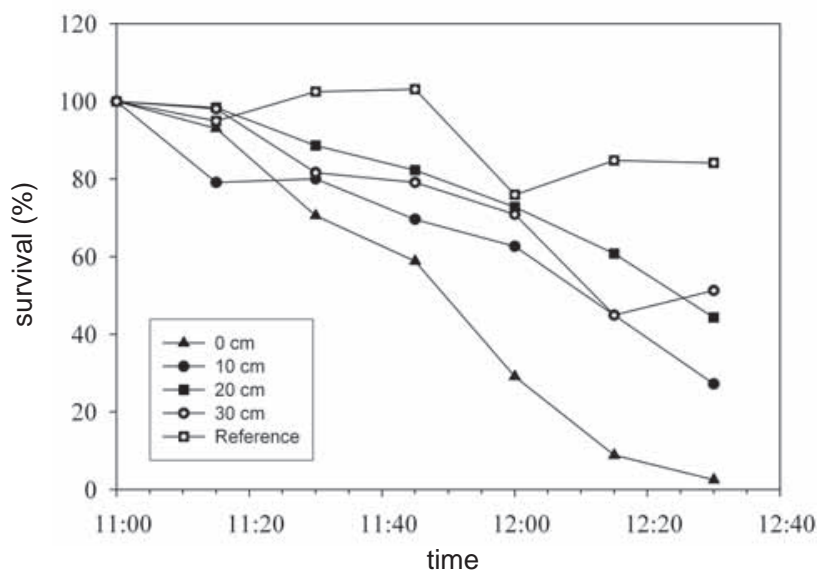

Fig. 4. Reduction of Escherichia coli in water tested at different depths using $500 \mathrm{mI}$ PET-bottles. Initial concentration of Escherichia coli: $3.0 \times 10^{4} \mathrm{cfu} / \mathrm{ml}$; UVB maximum: $190 \mathrm{~mW} / \mathrm{m}^{2}$. coli was reached after 1.5 hours, when tested at the surface. The germicidal effect tested at $30 \mathrm{~cm}$ showed a reduction rate of $50 \%$ only. Reduction rate of the dark reference can be neglected, as it is less than $20 \%$ (Fig. 4). The reduction of Escherichia coli at the surface and at a depth of $10 \mathrm{~cm}$ is significantly higher than in the depth of $20 \mathrm{~cm}$ and $30 \mathrm{~cm}$ and in the dark reference $(\mathrm{p}<0.05)$, but there is no significant difference between the dark reference and samples at depths of $20 \mathrm{~cm}$ and $30 \mathrm{~cm}$.

Determination of the influence of PET-bottles showed that Escherichia coli was totally eliminated after 50 minutes of sunlight exposure in both bottle sizes. The reduction rate of Escherichia coli in the bottles is significantly higher than in the dark reference $(p<0.01)$. Bacterial elimination was slightly faster in 0.51 bottle than in 21 bottle for the first $20 \mathrm{~min}$ (Fig. 5).

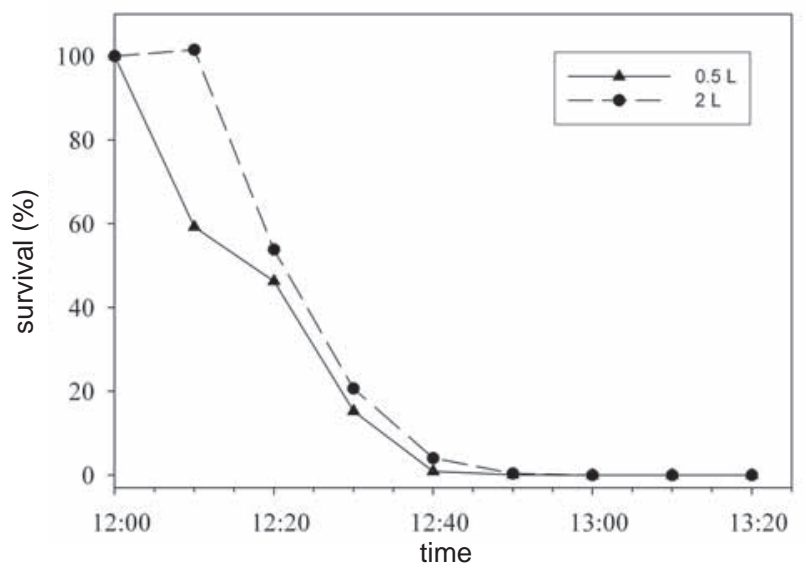

Fig. 5. Reduction of Escherichia coli in water in 0.5 I and 2 I PET-bottles. Initial concentration of Escherichia coli $2.5 \times 10^{4}$ cfu/ml; UVB maximum: $208 \mathrm{~mW} / \mathrm{m}^{2}$.

\section{DISCUSSION}

The reduction of coliform bacteria in surface waters depends on physiochemical factors such as solar radiation, salinity, heavy metals, sedimentation, coagulation and flocculation, nutrient deficiencies, predation by other microorganisms, lysis by bacteriophages, algae and presence of microbial toxins, furthermore by temperature, $\mathrm{pH}$ and oxygen saturation (17-19). Investigations of aquatic systems carried out by excluding sunlight showed survival times of indicator bacteria of days to even weeks (20). Thus, coliform decay is primarily the result of light-induced damage. No other single factor has been shown to be so clearly important (21). Because of direct effects on organic components of the cell and indirect effects by photochemical reactions in the surrounding water UV-B is an important factor in the elimination of microorganisms.

Solar radiation intensity varies over time and geographical location. The intensity of UV-radiation on cloudless days is three times higher than on completely overcast days. Reduction rates of Escherichia coli in Fig. 1 show a significant correlation with radiation intensity $\left(\mathrm{R}^{2}=0.92\right)$.

Suspended particles in water cause radiation scattering by deflection from their surfaces in all directions. Turbidity is used as a parameter to characterize the optical properties of liquids containing absorbers and scatterers. Turbidity reduces solar 
radiation intensity and protects microorganisms from being irradiated (being either under floating solids or in settleable solids) (22). The higher the UV transmittance, the higher the inactivation rate of microorganisms (14). For this reason every water environment, whether bathing water or drinking water, should be protected from influences which result in increased turbidity and so in decreased UV transmittance. The significant influence of UV transmittance on the reduction rate of Escherichia coli is demonstrated in Fig. 3.

Furthermore, we were able to show the reduction of radiation effects with increased water depth. Our experiments showed that best elimination of microorganisms occurred on the water surface and that reduction of microorganisms decreased with increasing depth of the aquatic environment (Fig. 4). Thus, the inactivation of microorganisms can be expected only at the surface.

Moreover, different microorganisms do not show the same sensitivity to UV radiation (Fig. 2). It is important to know their sensitivity to environmental influences such as sunlight, temperature, and $\mathrm{pH}$. It has to be considered that the inactivation of fecal indicator bacteria does not ensure the absence of any other pathogen microorganisms.

Solar radiation plays an important role in the inactivation of bacteria in water environments such as surface water used for recreational purposes. In artificial small-scale bathing ponds water is kept clean solely through ecosystems of micro-and macro-organisms; there is no additional disinfection of water. Therefore it is of great interest to determine factors responsible for elimination of bacterial impact (23). The significant inactivation of indicator bacteria shown in the present study proves that sunlight, given an appropriate intensity and good water transparency, is the most important factor in the reduction of fecal indicator bacteria in surface waters and, thus, also in bathing waters. It needs to be considered, that other factors such as water depth, turbidity, nutrients and sediments can favor the survival of microorganisms in water.

Furthermore, we observed the complete inactivation of Escherichia coli in PET-bottles within one hour. Contaminated water needs to be disinfected by heating or chlorine. However, people living in developing countries often do not have this opportunity. At least one third of the population in developing countries has no access to safe drinking water. Waterborne diseases are still common as drinking water sources are contaminated and feasible means to reliably treat and disinfect these waters are not available. There are about 4 billion cases of diarrhea per year, with 2.5 million cases ending in death. Every 15 th second a child dies of dehydration due to diarrhea. Many of these developing countries are in the tropical regions of the world where sunlight is plentiful. Several studies have shown the positive effect of polyethylene terephtalate bottles on transmitting all wavelengths in sunlight, so bottles made of that material are ideal for drinking water disinfection $(12,13,15,16)$.

People living in the towns of Alokoegbe (Togo), Cali (Colombia), Cochabamba (Bolivia), Yogyakarta (Indonesia) and Khon Kaen (Thailand) already profit from the bactericidal power of sunlight. They use PET-bottles exposed to sunlight to disinfect their drinking water. Since then their state of health has much improved (24). Our experiments demonstrate this important possibility to increase quality of drinking water. This method should become more popular especially in countries with low hygienic standards.

\section{Acknowledgements}

We are grateful to Evelyn Stelzl for critical review of the manuscript. We sincerely thank Richard Koudelka for providing meteorological data. Special thanks go to Herwig Friedl and Peter Trinkaus for the statistical analysis.

\section{REFERENCES}

1. Chamberlin CE, Mitchell R. A decay model for enteric bacteria in natural waters. In: Mitchell R, editor. Water pollution microbiology. Vol. 2. New York: John Wiley and Sons; 1978.

2. Clancy JL, Bukhari Z, Hargy TM, Bolton JR, Dussert BW, Marshall MM. Using UV to inactivate Cryptosporidium. J Am Water Work Assoc. 2000;92(9):97-104.

3. Fujioka RS, Narikawa OT. Effect of sunlight on enumeration of indicator bacteria under field conditions. Appl Environ Microbiol. 1982 Aug;44(2):395-401.

4. Joux F, Jeffrey WH, Lebaron P, Mitchell DL. Marine bacterial isolates display diverse responses to UV-B radiation. Appl Environ Microbiol. 1999 Sep;65(9):3820-7.

5. Sinton LW, Davies-Colley RJ, Bell RG. Inactivation of enterococci and fecal coliforms from sewage and meatworks effluents in seawater chambers. Appl Environ Microbiol. 1994 Jun;60(6):2040-8.

6. Davies-Colley RJ, Donnison AM, Speed DJ, Ross CM, Nagels JW. Inactivation of faecal indicator microorganisms in waste stabilisation ponds: interactions of environmental factors with sunlight. Water Res. 1999;33(5):1220-30.

7. Änderung des Bäderhygienegesetzes. BGBl Nr. 658/1996. (Nov 29,1996).

8. Pond K. Water recreation and disease: plausibility of associated infections: acute effects, sequelae and mortality. Geneva: WHO; 2005.

9. Mascher F, Pichler-Semmelrock FP, Koeck M, Nagl M, Richtarski U. Studies regarding the ecological and hygienic stability of a small mechanical bathing pond installation. Österr Wasser- Abfallwirtschaft. 2001;53 (7-8):198-203.

10. Korhonen LK, Martikainen PJ. Survival of Escherichia coli and Campylobacter jejuni in untreated and filtered lake water. J Appl Bacteriol. 1991 Oct;71(4):379-82.

11. ÖNORM M 5873-2. Plants for the disinfection of water using ultraviolet radiation - Requirements and testing - Part 2: Medium pressure mercury lamp plants. Wienna: Austrian Standards Institute; 2003. (In German.)

12. Sommer B, Mariño A, Solarte Y, Salas ML, Dierolf C, Valiente C, et al. SODIS - An emerging water treatment process. J Water SRT - Aqua. 1997 Jun;46(3):127-37.

13. Wegelin M, Canonica S, Alder AC, Marazuela D, Suter MJF, Bucheli TD, et al. Does sunlight change the material and content of polyethylene terephthalate (PET) bottles? J Water SRT - Aqua. 2001 Jun;50(3):125-33.

14. Wegelin M, Canonica S, Mechsner K, Fleischmann T, Pesaro F, Metzler A. Solar water disinfection: scope of the process and analysis of radiation experiments. J Water SRT - Aqua. 1994;43(3):154-69.

15. Wegelin M, Sommer B. SODIS at the turning point - a technology ready for use. SANDEC News. 1997 Oct;(3):1-10.

16. Wegelin M, Sommer B. SODIS: destined for worldwide use? Waterlines. 1998;16(3):30-2.

17. Gurijala KR, Alexander M. Explanation for the decline of bacteria introduced into lake water. Microb Ecol. 1990;20(3):231-44.

18. Howell JM, Coyne MS, Cornelius PL. Effect of sediment particle size and temperature of fecal bacteria mortality rates and the fecal coliform/fecal streptococci ratio. J Environ Qual. 1996;25(6):1216-20.

19. Karentz D, Bothwell ML, Coffin RB, Hanson A, Herndl GJ, Kilham SS, et al. Impact of UV-B radiation on pelagic freshwater ecosystems: report of working group on bacteria and phytoplankton. Arch Hydrobiol Beih Ergebn Limnol. 1994;43:31-69.

20. Mezrioui N, Baleux B, Troussellier M. A Microcosm study of the survival of Escherichia coli and Salmonella typhimurium in brackish-water. Water Res. 1995;29(2):459-65.

21. Evison LM. Comparative studies on the survival of indicator organisms and pathogens in fresh and sea-water. Water Sci Technol. 1988;20(11/12): 309-15. 
22. Pfammatter R, Wegelin M. Solar water disinfection: evaluation of field tests carried out in Cali, Colombia. Dübendorf: EAWAG; Cali: CINARA; 1993. Internal Report.

23. Mascher F, Deller S, Pichler-Semmelrock FP, Roehm S, Marth E. The significance of sunlight for the elimination of indicator bacteria in small-scale bathing ponds in central Europe. Water Sci Technol. 2003;47(3):211-3.
24. SODIS. Solar Water Disinfection. A Water Treatment Process used at Household Level [homepage on the Internet]. Dübendorf: SANDEC (Water \& Sanitation in Developing Countries); EAWAG (Swiss Federal Institute for Environmental Science and Technology; 2004 [updated 2006 Jun 24; cited 2006 Mar 1]. Available from: http://www.sodis.ch.

Received December 12, 2005

Received in revised form and accepted March 2, 2006 